\title{
Lithic and other non-ceramic artefacts
}

\author{
Peter Bellwood, Geoffrey Irwin, and Daud Tanudirjo
}

\begin{abstract}
During the course of the North Moluccan project, non-ceramic artefacts were recovered in only small numbers, with rather limited raw material or stylistic variation. Flaked stone tools were especially rare in comparison with many other pre-Neolithic locations in Southeast Asia. The site of Siti Nafisah produced no flaked stone at all, despite being fairly rich to its cultural base in animal bones, bone points, and shells (Table 4.1). Our general impression during the course of the research was that good cryptocrystalline raw materials such as chert, jasper, and agate are very rare in these islands (and only one piece of obsidian was found), such that people would have had to turn to inferior volcanic and metamorphic rocks for making stone tools. Perhaps they turned to alternative materials such as shell (Szabó et al. 2007; Szabó and Koppel 2015), although we did not find many finished shell tools in pre-Neolithic contexts, except for the shell adzes from Gebe. A series of bone points from Golo, Siti Nafisah, and Uattamdi have already been analysed and published by Juliette Pasveer (Pasveer and Bellwood 2004). As with the Golo lithics (below), detailed descriptions are not repeated here, except for the shell artefacts discussed by Katherine Szabó in the next chapter.
\end{abstract}

\section{The flaked lithics from Golo and Wetef}

Golo produced both flaked stone and marine shell (some worked) in relatively small amounts to its base at 35,000 cal. BP, with a very distinct shrinkage in quantity over the course of the Last Glacial Maximum (Table 2.2). A number of worked Turbo marmoratus opercula from the basal layers in Golo, as well as the Golo flaked lithics made of coarse chert and metamorphic rocks, none with any particular diagnostic features, have been fully reported elsewhere by Katherine Szabó and Adam Brumm (Szabó et al. 2007). There is no retouch, and it was suggested by Brumm that many lithic items were flaked elsewhere and brought into the cave, such that large cores were absent in the deposits.

A total of 22 stone artefacts similar to those from Golo was also recovered from nearby Wetef rockshelter, Squares K3 and K4. They were made on a range of volcanic, metamorphic, and chert-like rocks of generally low quality, available nearby in central and eastern parts of Gebe. Flaked stone was most frequent in Layer D, but smaller quantities occurred in Layers B and C, without indication of technological change. The most common type at Wetef was flake shatter $(n=12)$, followed by simple unifacial flakes $(n=9)$. There were no formal cores and only one hammerstone, which weighed $116.9 \mathrm{gm}$. 


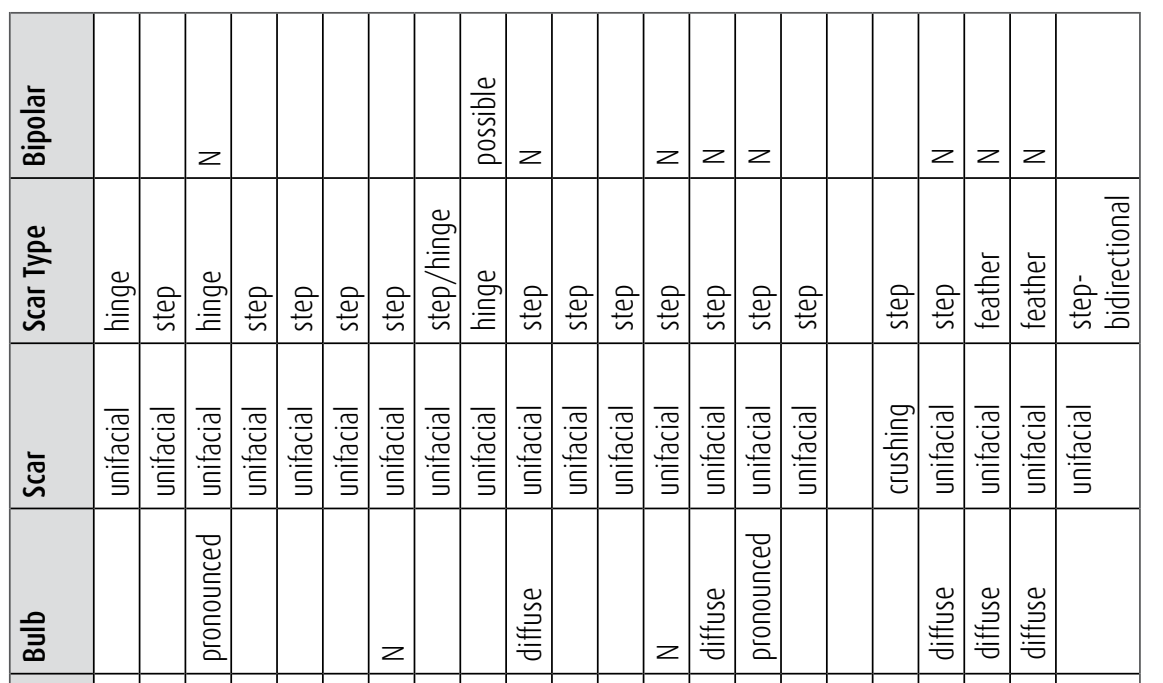

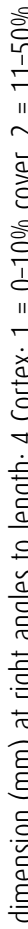

\section{틀}

$z$

$z$

$>z$

$z=$

$z>>$

$>>z$

產

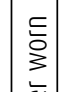

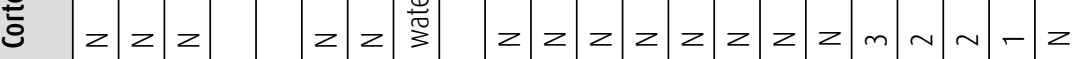

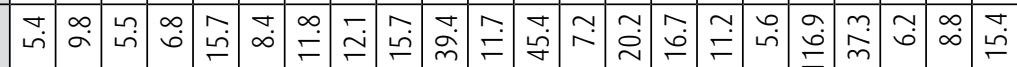

蒙

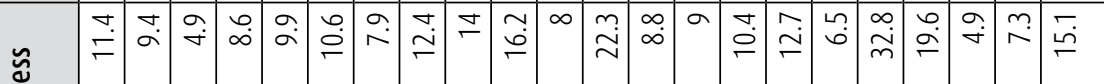

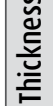

喜

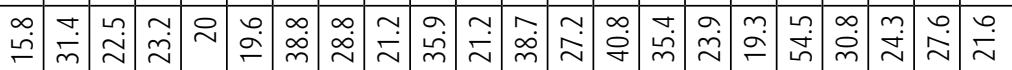

突

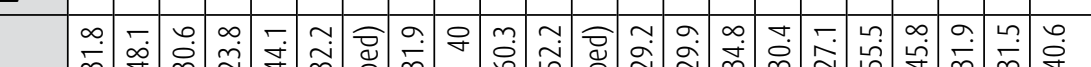

跑

壳

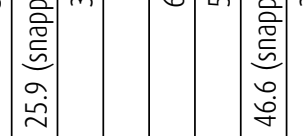

๕

$\stackrel{\overbrace{}}{\frac{\pi}{0}}$

$\stackrel{\mathscr{c}}{\stackrel{0}{n}}$

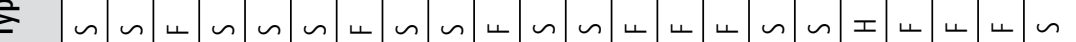

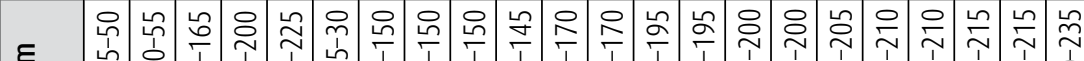

E

ธิे

غ்

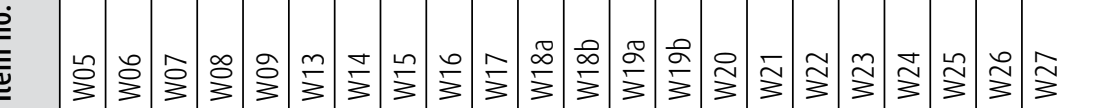

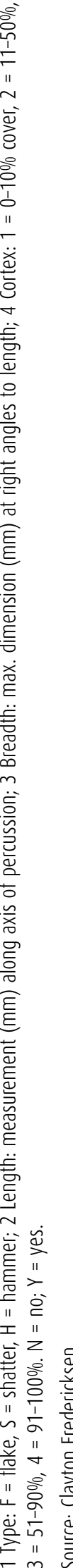


The Wetef lithic collection was examined in Auckland by Clayton Fredericksen and the results of his study are presented in Table 8.1. Artefacts (not illustrated here) were technologically straightforward with no evidence of formal tools or intentional retouch. Knapping involved freehand unifacial flaking with a hard hammer, and there was only one example of possible bipolar flaking. No flake or debitage measured less than $23.8 \mathrm{~mm}$ in maximum dimension, suggesting that many flakes could have been struck elsewhere, as with the Golo assemblage (Szabó et al. 2007). Possible use-wear on artefacts W14 and W20 was observed under X10 magnification, and there were red/brown residues on W14, W24, and W26. Cortex remained on three flakes and the hammerstone. The primary aim of the lithic technology in both Wetef and Golo was the production of simple steep-edged flakes, probably for cutting and scraping.

\section{The Morotai beach-pebble and flake industry}

As noted in Chapter 3, Layer 1 in the Tanjung Pinang rockshelter contained an industry of flaked beach pebbles and struck debitage, together with a large number of unflaked and apparently unmodified beach pebbles that presumably served as manuports of uncertain function (Figs 8.1 and 8.2). Many of these items were left in the Sultan Palace Museum in Ternate in 1994, but the debitage from the 1994, 4x1 m trench F2 to J2 was brought to Canberra, as were those beach pebbles that showed definite signs of flaking. The debitage material itself is difficult to analyse since much of it shows the kind of fracturing that can often also be associated with the shattering of heated oven stones. The raw material is also very coarse volcanic or metamorphic rock, not amenable to use wear analysis. But quite a few pieces show definite conchoidal flaking, and some have edge abrasion indicating intentional use. None are retouched, and none have any features (e.g. blade morphology or backing) that could be defined as diagnostic at a cultural level.

In Chapter 3, the issue was raised of whether or not this industry continued in use into the late phase of skull and pottery deposition in the site. This will always be uncertain, since some of the skulls are sufficiently well preserved to indicate burial in pits deep enough to remove them from the activities of scavengers such as pigs and dogs, both presumably present on Morotai by 2000 years ago. So, quite deep disturbance is obvious for such preservation to have occurred. The same problem occurs in Daeo 2, where a similar beach pebble-based lithic industry (not described separately in this report) occurs with human bones in the upper spits, and also continues below the bones to the base of the site. Such flaked lithics were, however, not found in the open sites that we excavated on Morotai (Sabatai Tua, Sambiki Tua), or even in the pottery-bearing cave of Tanjung Tulang, so it appears most unlikely that pebble industries of this kind continued in use more recently than 2000 years ago. Furthermore, purely flaked, as opposed to ground or polished, lithics were rare in all the non-Morotai Neolithic deposits that we excavated in the Northern Moluccas, for instance in Uattamdi, Buwawansi, and the Neolithic layer in Siti Nafisah. Um Kapat Papo produced only 12 pieces of flaked stone in total— too few for any useful statement to be made. 


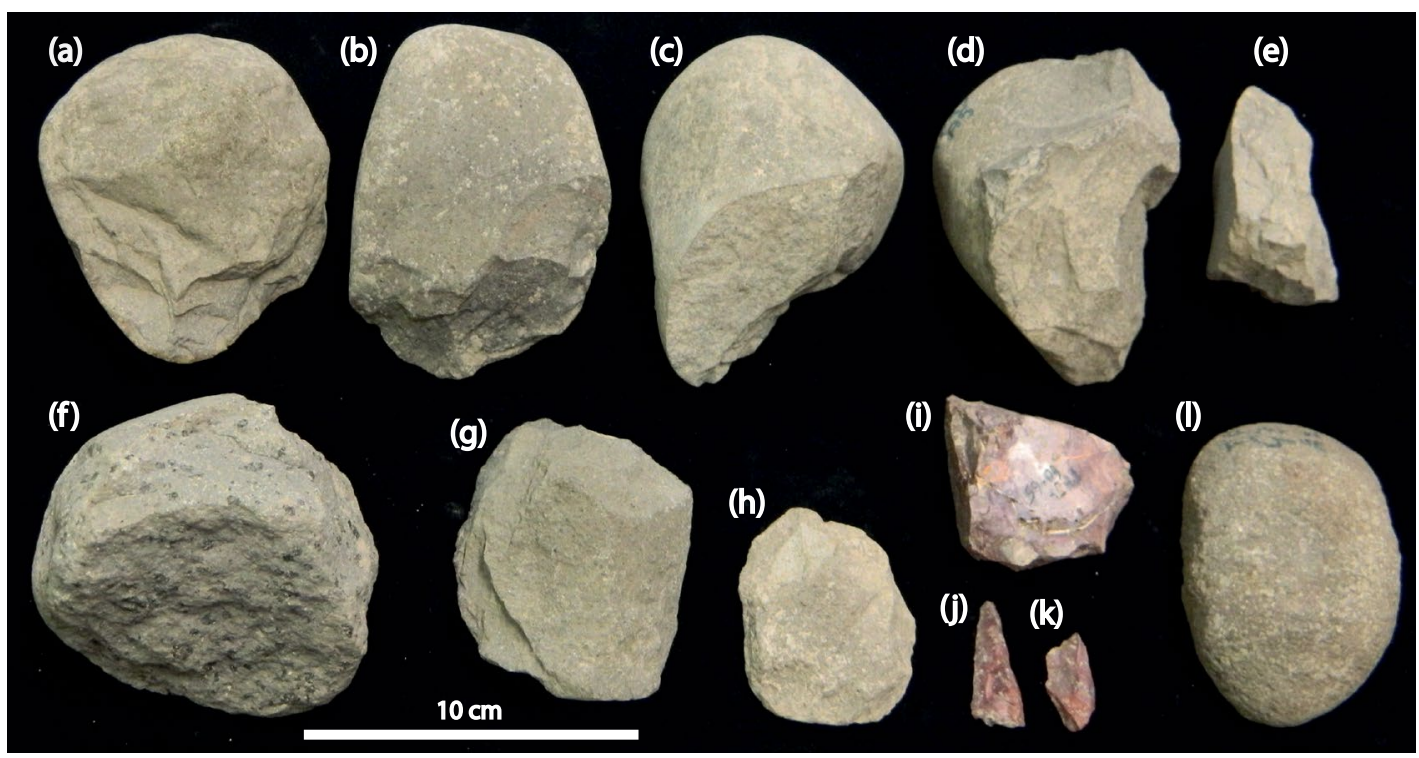

Figure 8.1 Lithics from Tanjung Pinang.

(a)-(c): unifacially flaked pebbles; (d)-(e) and (g): steeply flaked pebbles; (f): horsehoof core with battered edges; (h): large flake with flake scar on dorsal surface (Sumatralith); (i)-(k): flaked pieces of chert; (l): Canarium anvil.

Source: Peter Bellwood.

Figures 8.1 and 8.2 illustrate a number of flaked lithic pieces from Tanjung Pinang. Items (a) to (c) are simple unifacially flaked pebbles, of a form typical of other contemporary pebble industries such as the Indochinese and Sumatran unifacial Hoabinhian. This is probably coincidental, reflecting no more than a focus on a use of pebbles as raw materials. Items (d), (e), and (g) are steep-edged and rather scraper-like pebble tools. Item (f) is a battered horsehoof core of very coarse volcanic rock. Items (d) to (g) resemble early tools in Australia, being generally in the steep-edged and horsehoof mode, but again the parallels might be coincidental since at this very basic level of pebble flaking the chances of overlap in form are obviously very high indeed. Item (h) is a small unifacial Sumatralith, to use a Hoabinhian terminology, made on a fairly large flake that still preserves its ventral surface. Items (i), (j), and (k) are of coarse red-brown chert, a flaked chunk and two blade-like flakes. Since the latter were rare in Maluku Utara (e.g. Fig. 8.2) it is best to regard them also as fortuitous. The Moluccas certainly have not produced any traces of a backed blade-like flake and microlith industry such as the Toalian in southwestern Sulawesi.

Item (l) in Figure 8.1 is a form of stone anvil found quite commonly in the Northern Moluccas, being a river or beach pebble with a pounded hollow on each side. Informants suggested these might have been used to open the very hard-shelled nuts of the Canarium tree genus. The stratigraphy associated with these anvils in Tanjung Pinang (no less than 20 in this site; Table 3.1) and Golo suggests that they originated in preceramic times, possibly in the late Pleistocene, given that one coral specimen came from a depth of $200 \mathrm{~cm}$ in Golo, possibly with an age of 30,000 years. One of the Tanjung Pinang specimens (different from the one in Fig. 8.1) is drawn for clarity in Figure 8.2 (lower-right inset). 


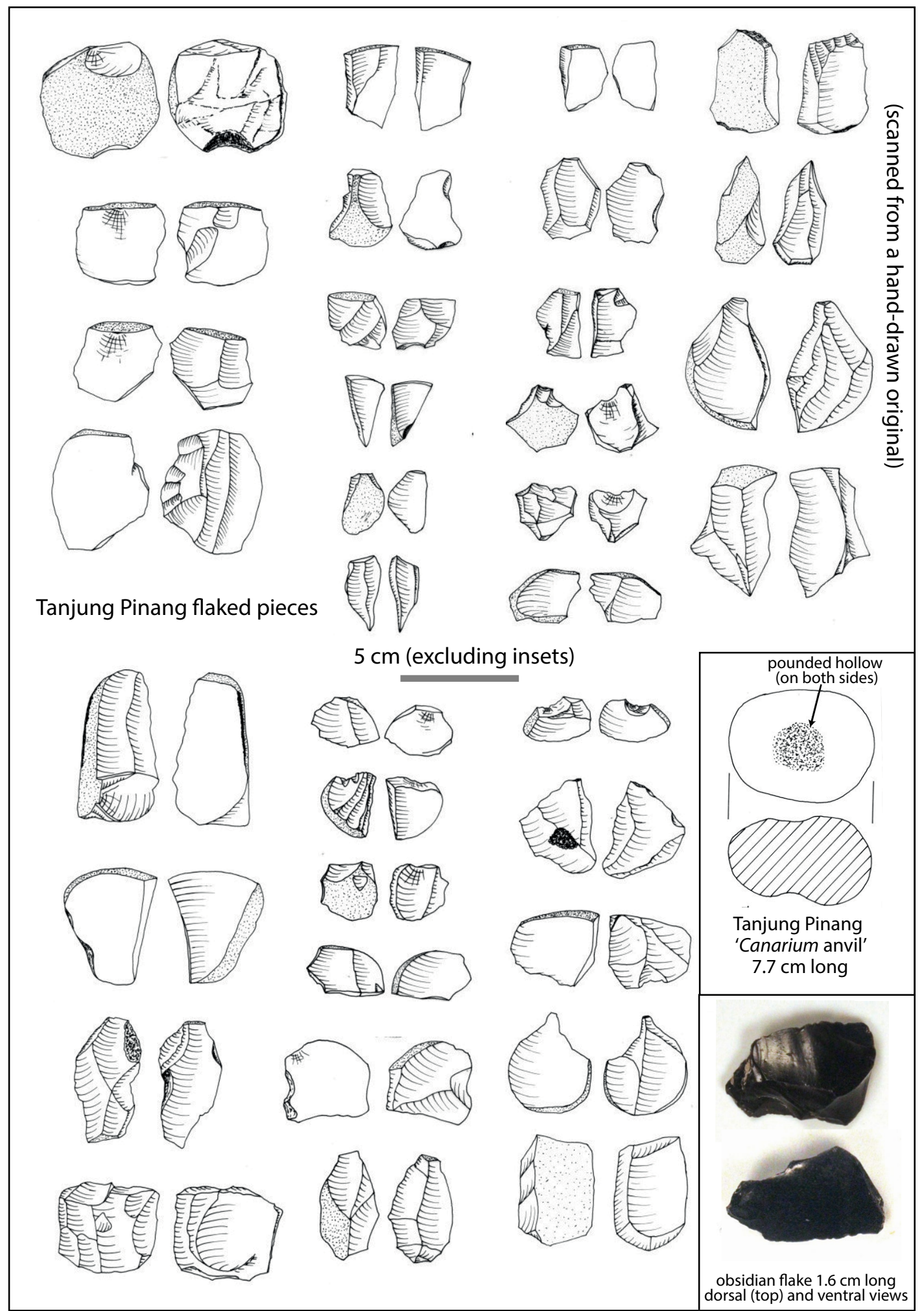

Figure 8.2 Flaked lithics struck from beach pebbles, a Canarium anvil and an obsidian flake from Tanjung Pinang.

Insets are not to scale.

Source: Daud Tanudirjo, Christian Reepmeyer, and Peter Bellwood. 
Figure 8.2 shows a number of flaked pieces from Tanjung Pinang, many with some remaining cortexed beach pebble exterior. None of these flakes have stone adze polish of the type visible on some of the stone flakes from Neolithic Uattamdi (below). None shows positive retouch, and while occasional pieces have blade-like proportions it appears that these result from intentional unidirectionality of flaking, rather than any specific intention to produce a blade industry. The item at top left in Figure 8.2 has a quite heavily worked notch.

One remarkable Tanjung Pinang find from a depth of $15-20 \mathrm{~cm}$ in Square F3 was a small piece of obsidian, $16 \mathrm{~mm}$ long by $12 \mathrm{~mm}$ wide (Fig. 8.2, lower-right inset), and possibly associated with the human skull burials since it was found at their level in the site. This piece was examined initially during the 1990s by Wal Ambrose at ANU, who recorded a density of 2.271 for the raw material, then by Glenn Summerhayes, now of the University of Otago, who was unable at that time to trace the piece by geochemical sourcing to any known origin. However, in 2014, the piece was sent to Christian Reepmeyer at James Cook University, who was able to use the current obsidian database for Island Southeast Asia and Melanesia to make the following statement:

Geochemical fingerprinting of the obsidian artefact points to one of the West Fergusson sources, most likely to the sub-source of Kukuia in the D'Entrecasteaux group. The second sub-source in this group, the Fagalulu source, can be excluded based on its higher Sr-values. Multivariate statistical analysis excluded all known Indonesian and Philippine sources (Christian Reepmeyer, email 25 January 2017).

West Fergusson obsidian is reported in small quantities from surface collections along the Sepik coastline of northwestern Papua New Guinea (Golitko et al. 2012), apparently from postLapita cultural contexts. The Tanjung Pinang occurrence is its first potential identification in an Indonesian archaeological site, and the significance of this will be discussed in Chapter 13. Added to the Golo and Wetef shell adzes with their Admiralty Island parallels (see below), and the Uattamdi and Tanjung Pinang pottery with its Collingwood Bay parallels (Chapter 7), it is becoming clear that periodic episodes of interaction involving the Moluccas did occur along the coastlines of or around the island of New Guinea from mid-Holocene times onwards. However, it is equally important to note that the Talasea and Admiralty obsidian sources so important in linking northern Borneo (Bukit Tengkorak, see Bellwood 1989) and the western Melanesian islands during Lapita times (c. 3000 BP) are completely absent (so far) in the Northern Moluccas, as also is any trace of any early Lapita connection in pottery decoration.

\section{The Neolithic stone assemblage from Uattamdi 1}

The lithic tools from Uattamdi 1 were restricted in distribution to Neolithic Layers C and D inside the rockshelter, and absent in the Metal Age jar burial Layers A and B above. Table 5.1 shows the stratigraphic distribution of the recovered assemblage: three complete adzes, one adze bevel, eight adze chips and other fragments with polish on one surface, and 25 unpolished flakes, cores and other debitage. The common occurrence of polished stone in this assemblage, compared with its complete absence in Tanjung Pinang, supports the comment above that the Tanjung Pinang pebble industry is likely to be entirely preceramic in date.

The three complete adzes are shown in Figure 8.3: (a) is a partially polished lenticular crosssectioned adze of dark basalt, with a definite asymmetric adze (not axe) bevel on the side facing up in the right-hand drawing; (b) is a well-polished chisel of a similar basalt, again asymmetrically bevelled; and (d) is an edge-ground cutting tool made on a long piece of limestone, with an oval cross-section, that shows no sign of flaking. Its general shape is axe-like, but this specimen is clearly somewhat ad hoc in origin. 
Item a was found in Square D8 in Layer C9, quite close to the base of the site and within range of a date around $3000 \mathrm{BP}$ or before. Adzes of this untanged and lenticular-sectioned type also exist in contemporary Lapita sites in Island Melanesia (e.g. Kirch and Yen 1982:Fig. 92 for the Kiki Lapita phase in Tikopia), but their distribution in Indonesia is quite difficult to track owing to rarity of sufficiently detailed reports. There appear to be none in the northern Philippines or Taiwan (Hung 2004; Bellwood and Dizon 2013), so this form could be specific to Southeast Indonesia and western Oceania. I am not aware of any such close parallels elsewhere in Indonesia. Lenticular-sectioned slate adzes occur in the Kalumpang sites (Minanga Sipakko and Kamassi) in West Sulawesi, but these sites also have tanged and quadrangular-sectioned forms (van Heekeren 1972:Plates 98-99; Anggraeni 2012:Fig. IV.47) that do not occur in the Moluccas.

A small butt fragment (not illustrated) of a planilateral-sectioned adze from Uattamdi Square E5, Layer C6, also resembles a complete Lapita adze illustrated by Green (1979:Fig. 2.4) from Nenumbo, Main Reef Islands, Southeast Solomons. The Uattamdi chisel (item (b), from Layer D1) is an interesting piece with widespread parallels as far away as the Batanes Islands and Pitcairn in Polynesia (Bellwood and Dizon 2013:Fig. 8.5). Another very small (14 mm long) bevel fragment from a similar chisel was found in Square C7, Level D1 (not illustrated). The Pitcairn specimen is also drawn as item (c) in Figure 8.3.

In 2015, Matthew Spriggs at ANU showed Peter Bellwood a number of stone adzes found with late Lapita pottery on a coral reef in the DES site on Nissan Island, between New Ireland and Bougainville in eastern Papua New Guinea. The adzes are of the same untangled lenticular and planilateral-sectioned forms present at Uattamdi, and there are also chisels with oval or plano-convex cross-sections. These similarities are quite striking, especially given the movement of Talasea obsidian from New Britain into the site of Bukit Tengkorak in Sabah at the same time (Bellwood 1989). However, the perspective discussed in Chapter 7, and reinforced in the concluding Chapter 13, is that this does not necessarily demand an origin for the Lapita complex as a whole in the Moluccas.

The flaked pieces shown as (e) to (o) in Figure 8.3 are quite varied in raw material and are described in the caption to the figure. Items (e), (k), and (l) each show one polished adze surface. Quartzite core (m) and chert flake (o) both show signs of heavy use wear. No blade-like forms are present and there is no intentional retouch, but these flakes are interesting in that they document a continuing usage of such items into the Neolithic in the Northern Moluccas. While this might seem rather a trivial observation, it takes on relevance in light of the rarity of flaked stone tools in many Neolithic sites to the west and north-for instance the Kalumpang sites in West Sulawesi, and the Batanes Islands (Anggraeni et al. 2014; Bellwood and Dizon 2013:Fig. 8.1). In the north Moluccan context these items might reflect a continuation of preceramic technology into a lithic environment dominated by polished adze and chisel production. 

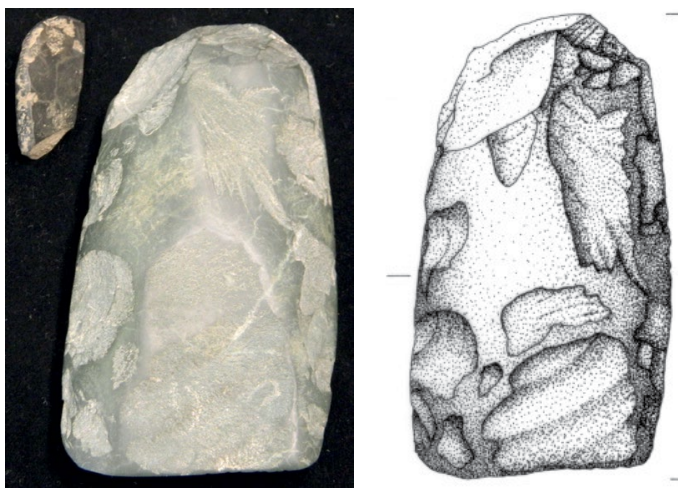

(a)
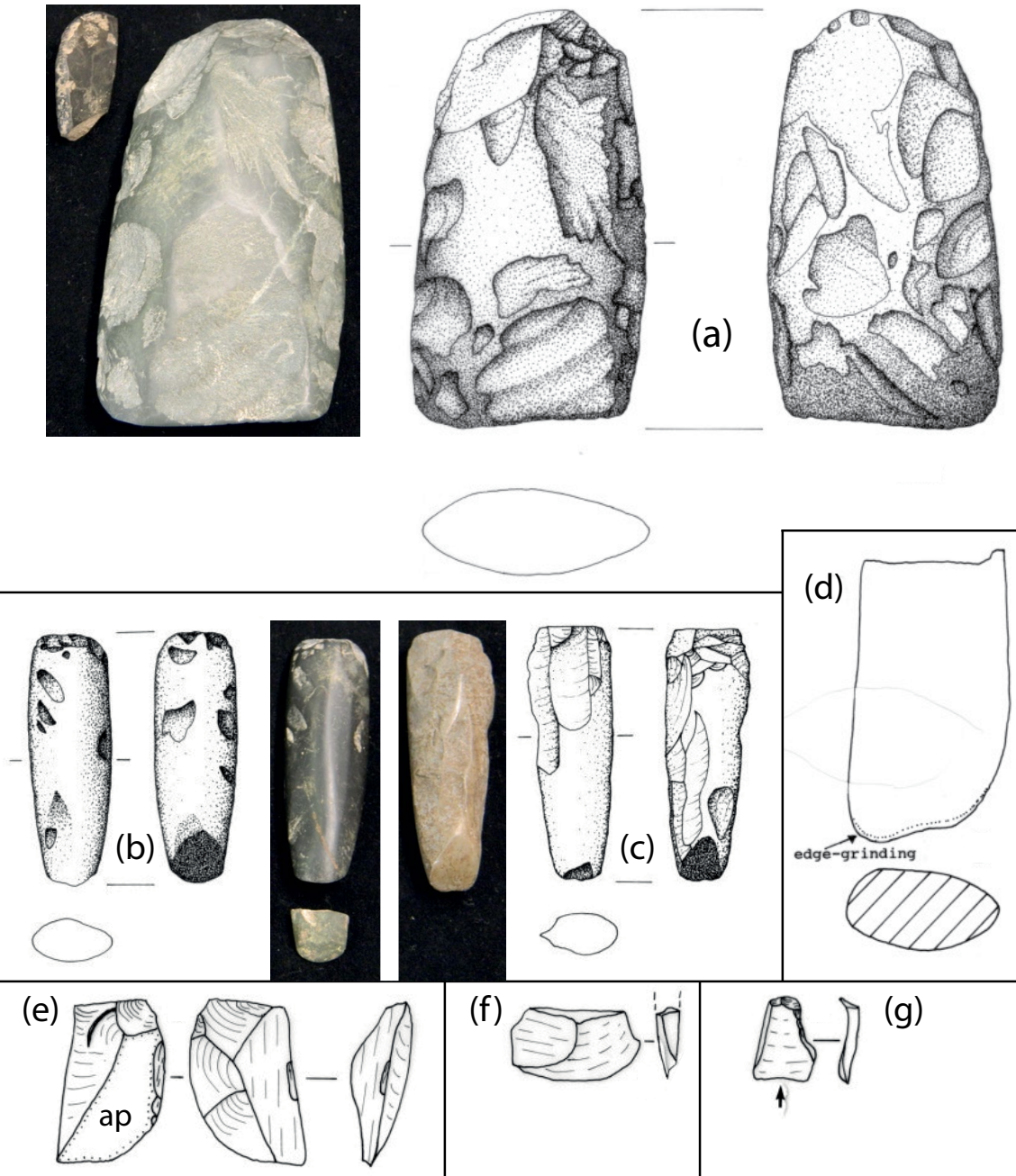

(f)
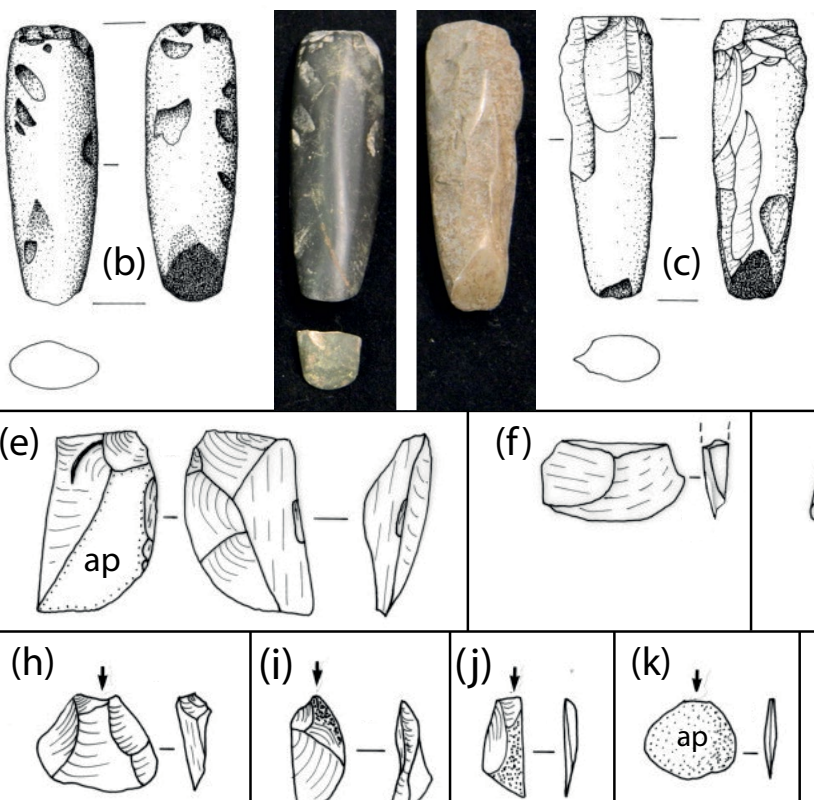

(i)

(j)
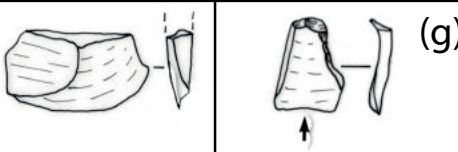

(g)
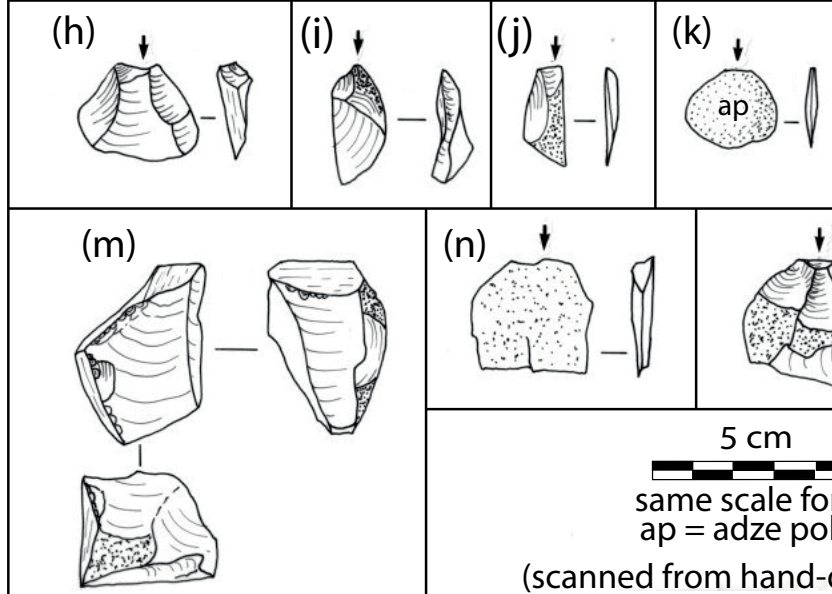

(I)
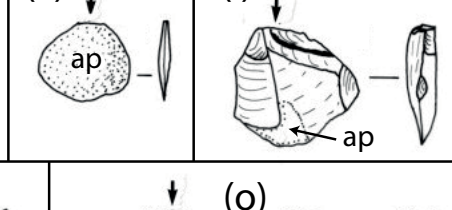


\section{Two Neolithic stone adzes from Gua Siti Nafisah, Halmahera}

Although Gua Siti Nafisah produced no flaked lithics at all, the Neolithic deposit in this cave produced two segments of polished stone adzes (Fig. 8.4). Item (a) is a butt or blade fragment (there is a possible bevel at the top of the drawing) of a paler grey volcanic rock than the adzes from Uattamdi. Its cross-section tends towards plano-convex rather than symmetrically lenticular, but in its degree of flaking and general shape it resembles the Uattamdi adze shown in Figure 8.3(a). This adze came from Layer B1 in Square F8, from which there is a date of 3443-3080 cal. BP (ANU 7785). If this date is applicable to the adze, then it is very close in date to the specimen from Uattamdi. However, the bulk of the pottery in the site was at a higher level, and more likely associated with the dates of 2351-2007 and 1598-1268 cal BP (Tables 1.1 and 4.1).

The other adze butt is an unusual fragment made on a strongly laminated rock, perhaps metamorphic, which appears to have been hammer-dressed rather than flaked into shape (Fig. 8.4(b)). This came from Square J10, at the base of the stratigraphy beneath the shell midden dated 1598-1268 cal. BP. The cross-section is again lenticular, like the other Uattamdi and Siti Nafisah examples, and the butt is quite strongly tapered.

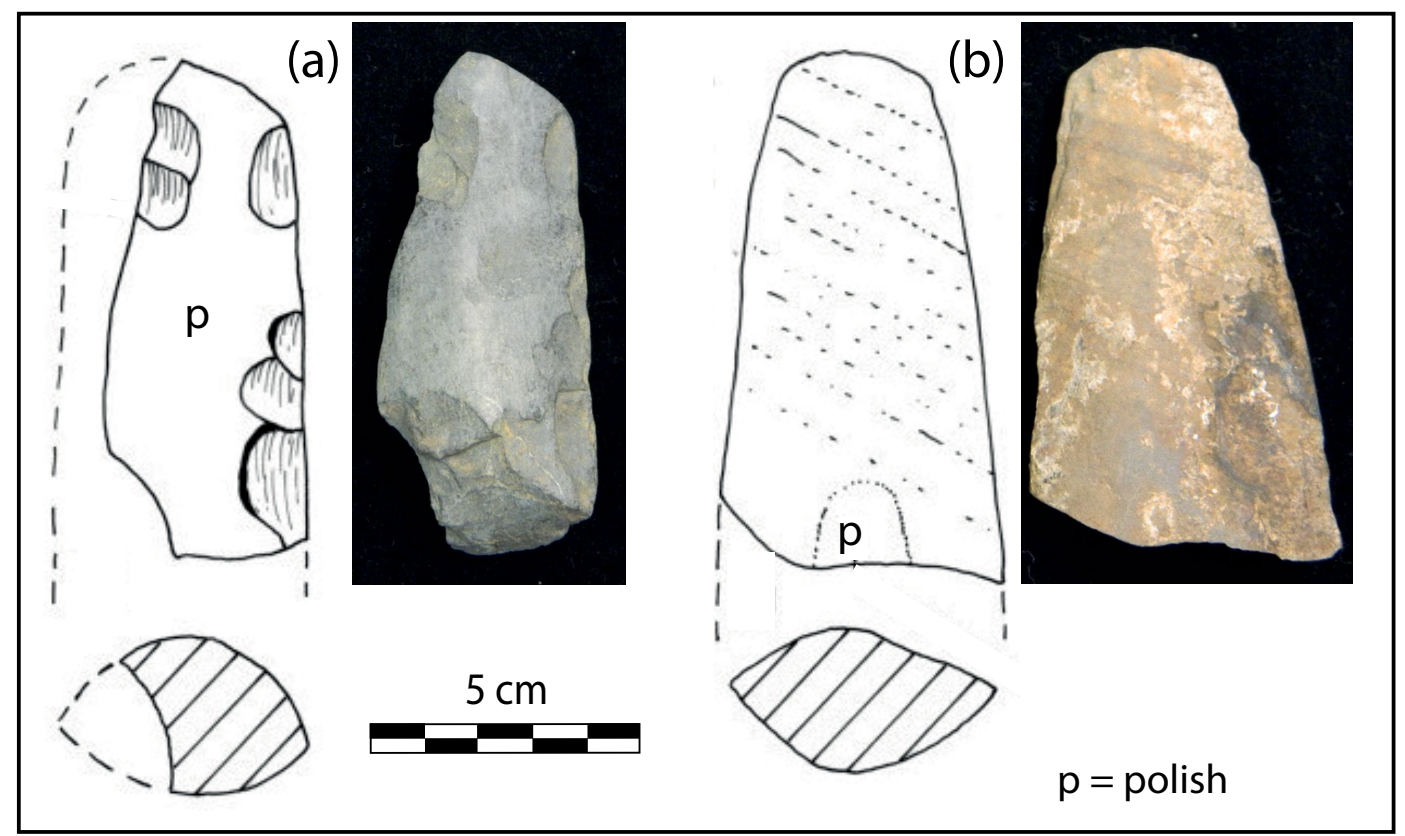

Figure 8.4 Stone adze segments from Gua Siti Nafisah, Halmahera.

(a): paler grey volcanic rock, flaked and polished; (b): laminated and possibly metamorphic rock, hammer-dressed rather than flaked, but also polished.

Source: Peter Bellwood.

\section{Facetted ochre pieces from the Golo Cave burial pit}

As noted in Table 2.3, the Golo Cave extended burial (2314-1415 cal. BP - ANU 11818) was placed in a grave filled with soil mixed with powdered-red ochre (hematite), together with the discarded ochre pieces from which the powder had been ground. Roughly 80 of these ochre pieces were recovered from within the grave fill, and a number of them were quite large, tabular in shape, with one ground flat surface from which the ochre powder had been scraped. A sample of 15 of the larger pieces are shown in Figure 8.5. The two pieces at bottom right have narrow grooves made by scratching with a pointed tool. 


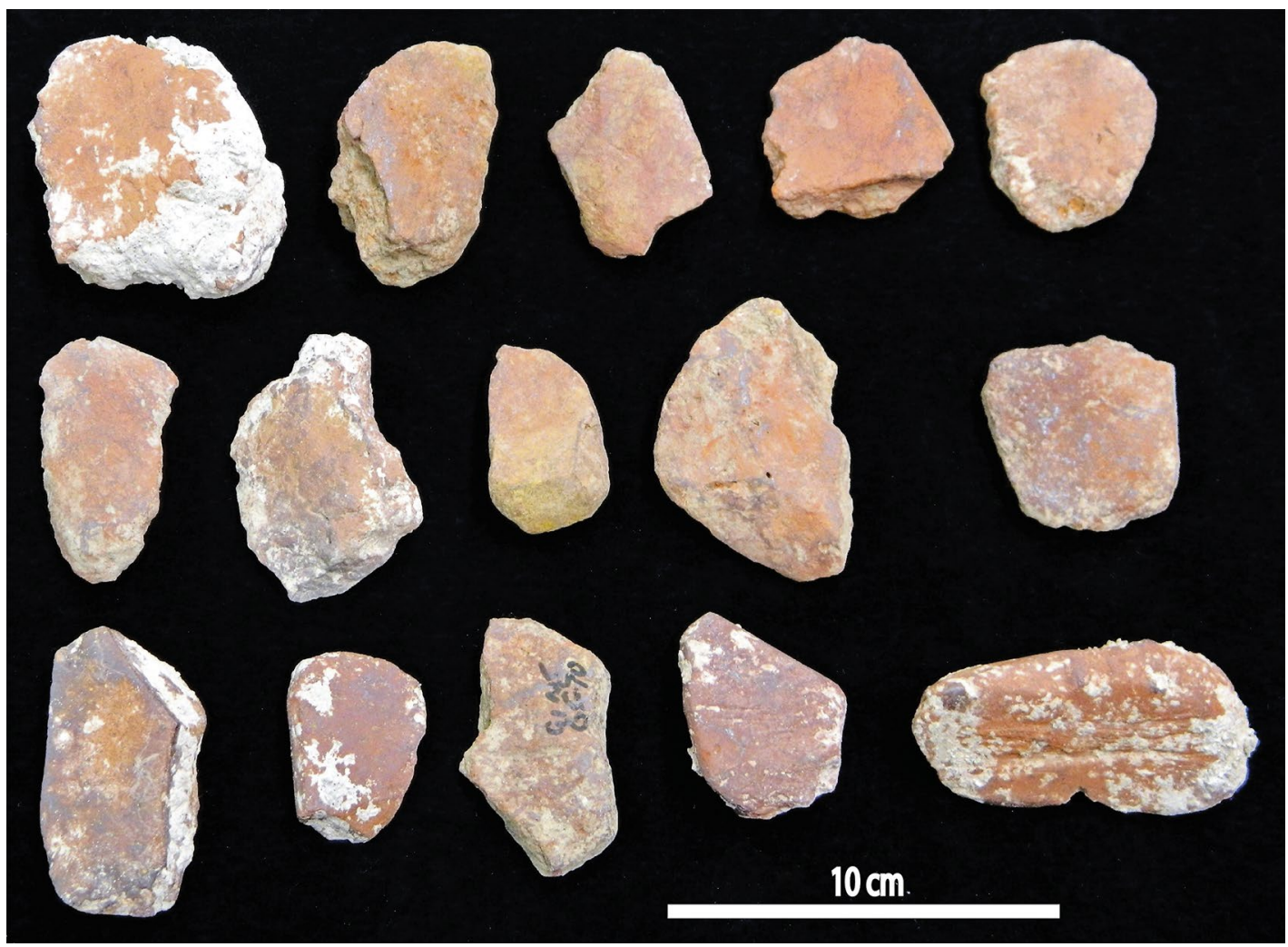

Figure 8.5 Ground ochre tablets from the Golo Cave burial fill.

The two specimens at bottom right have linear incisions.

Source: Peter Bellwood.

\section{The shell adzes from Golo, Wetef, and Buwawansi}

The shell artefacts from the Gebe excavations are dealt with in detail in the next chapter by Katherine Szabó. But two shell adze topics require discussion here. Wetef rockshelter produced a number of Cassis shell adzes not described in the next chapter, so they are described here first by Geoffrey Irwin. After this, we discuss the chronologies for the numerous Golo shell adzes, especially the Hippopus and Tridacna ones, which pose difficult problems.

\section{Cassis shell adzes from Wetef rockshelter}

Several complete and broken shell adzes made from the lip of Cassis shell, of the same form as at Golo (Fig. 8.6, compare Fig. 9.5 for Golo), were found at Wetef, all in Layer B1. One complete adze near the top of the layer measured $112 \mathrm{~mm}$ long and another, from the bottom of Layer B1 and illustrated in Figure 8.6, was $105 \mathrm{~mm}$ long, $35 \mathrm{~mm}$ wide at the bevel, and $23 \mathrm{~mm}$ thick. A third near-complete adze, missing part of the butt end and evidently burnt in a fire, came from the middle of Layer B1. In addition, there were seven other fragments of Cassis adze, some from the butt or the bevel, and others from the mid-section. Some of these pieces could have come from the same artefacts, but not all. Several of these fragments appear to have been broken in use and several had been subsequently discoloured by heat from fires. 


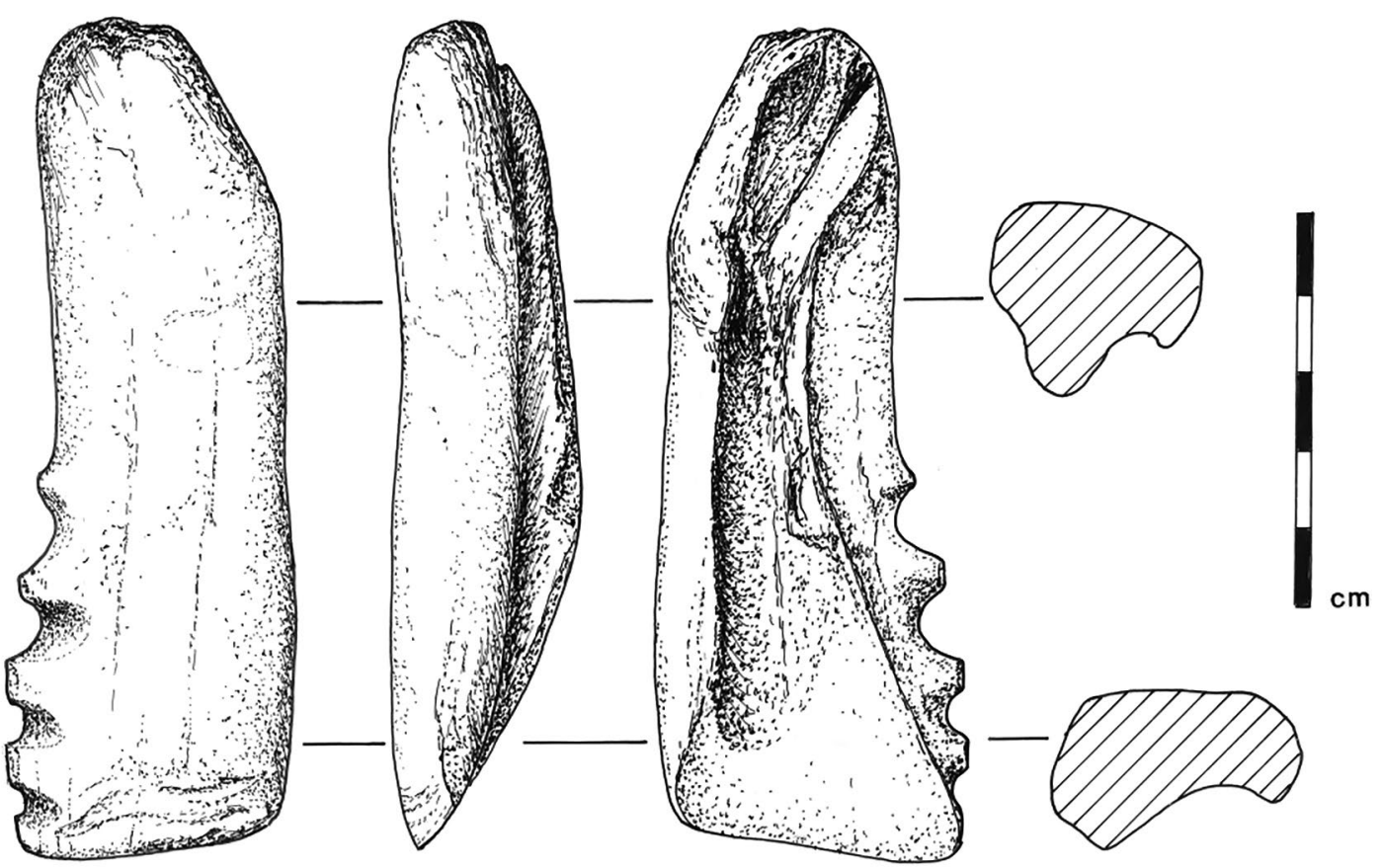

Figure 8.6 A Cassis shell adze from Wetef.

Source: Geoffrey Irwin.

The distribution of these shell adzes is problematical. None were contemporary with the potsherds of Layer A, although Cassis shell adzes are widespread in Oceania where they are always contemporary with pottery (e.g. Kirch and Yen 1982:226 for Tikopia; Carson 2014:Fig. 10.11 for House of Taga, Mariana Islands; Galipaud et al. 2016 for Pain Haka, Flores). Unlike Golo, none appeared during excavation to have been cached from above, and it is perhaps unlikely that broken pieces would have been deliberately buried, or that they all could have been carried down into Layer B1 by disturbance. Unfortunately, none of the Wetef samples submitted for direct radiocarbon dating produced a result. Their apparent preceramic context is anomalous. Or it could raise the possibility that these artefacts have a greater antiquity in Maluku and Island Southeast Asia than further east. However, a positive claim for this at present would be unwarranted.

\section{Dating the Golo shell adzes}

There are hints of external contacts reaching Gebe Island during the middle Holocene in the form of six non-Cassis ground clam shell adzes from preceramic contexts. These include three from Golo and one from Buwawansi made from the ventral hinge regions of large Tridacna clam shells (T. maxima or T. gigas), and two from Golo made from the ventral hinge regions of large Hippopus hippopus clam shells (Figs 8.7, 9.4, and 9.9). Four of these adzes (three Tridacna and one Hippopus) are described in more detail by Katherine Szabó in Chapter 9.

The Tridacna examples are paralleled closely by Tridacna adzes with similar hollow backs in late Pleistocene or early Holocene layers in Pamwak Cave in the Admiralty Islands (Fig. 8.7), located to the north of the Papua New Guinea mainland and about $2000 \mathrm{~km}$ due east of Gebe (Fredericksen et at. 1993; Schmidt 1996). The two Golo and Pamwak adzes shown in Figure 8.7 are identical in manufacturing technique, although the Pamwak example illustrated appears to have heavy cutting-edge use wear, and so is shorter than that from Golo, which shows only slight signs of use. The Pamwak adzes are dated indirectly to between 5500 and 11,000 BP (Fredericksen 
et al. 1993; Schmidt 1996). Daud Tanudirjo (2001) also reports such Tridacna adzes from the Sula Islands that lie east of Sulawesi, and Sue O'Connor informs us (pers. comm. May 2019) that similar Tridacna and Hippopus adzes have been found in Timor. Alfred Pawlik and colleagues (2015) have recently published information on other ground shell adzes of a similar Holocene and pre-Neolithic date from the Philippines and eastern Indonesia, although the Golo-Pamwak parallel appears to be the closest at present in terms of actual shape and cross-section, especially in the choice of shell used and the emphasis on the hollow back. The Golo and Pamwak specimens are indeed almost identical.

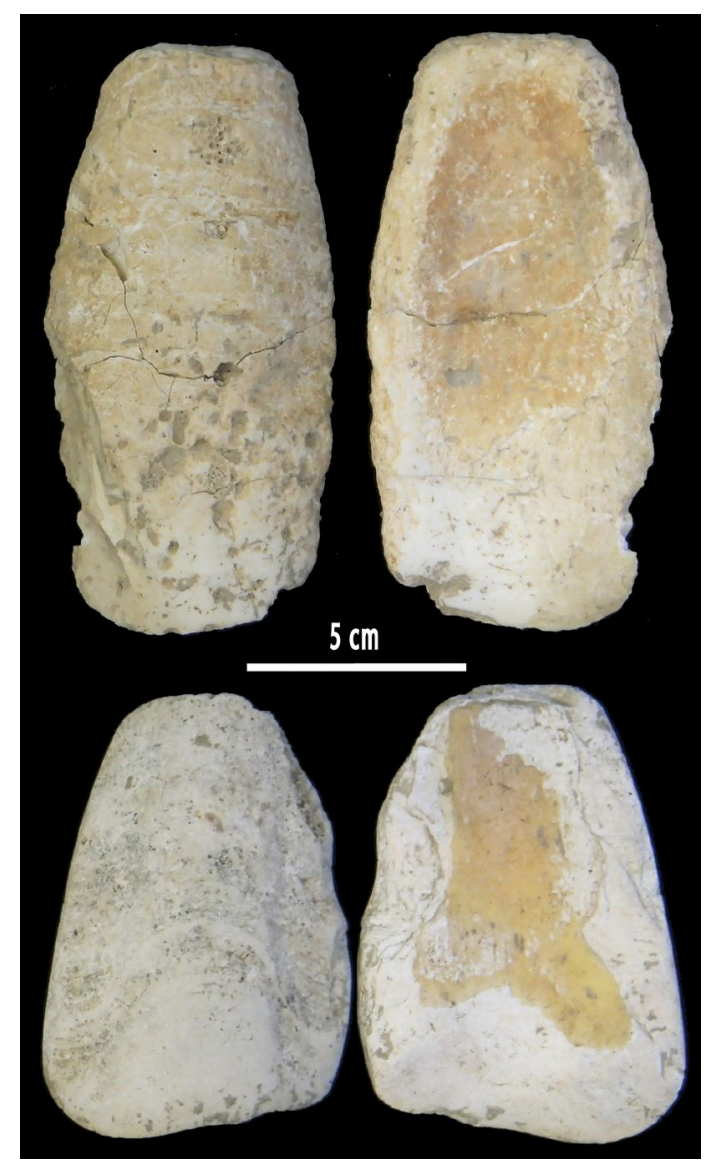

Figure 8.7 Tridacna shell adzes (photographed from both sides) from Golo M4 135-140 cm (top) and Pamwak Cave (Square 2, spit 4), Manus, Admiralty Islands (bottom).

Source: Peter Bellwood. Pamwak adze courtesy of Matthew Spriggs.
The Golo clam shell adzes were found in a level proxy-dated between 12,000 and 9000 years ago based on C14 dates from nearby food shells, and indeed I attributed this date to them in the second edition of my Prehistory of the Indo-Malaysian Archipelago (Bellwood 2007: Plate 25). However, since the majority of these tools were complete and undamaged, a moment's thought will indicate that they were all cached in holes in the cave floor, presumably by itinerant visitors who intended to reuse them during some future visit to the site. Therefore, they must have been younger than the stratigraphic dates just given, perhaps by several millennia. Exactly how old were these large clam shell adzes?

The obvious course of action, applied some years after the excavations finished, was to radiocarbon date the actual shells from which the Golo adzes were made. The results came as something of a surprise. One of the Tridacna adzes from 135-140 cm (a depth dated stratigraphically to c. 12,000 years ago) gave a reading of 38,984-34,638 years BP (OZD775), indicating that the maker did not use a new shell but found one either in a beach deposit or eroding from one of the many uplifted segments of Pleistocene coral reef that line the Gebe shoreline, especially on the northern side of the island. The same applied to one of the Neolithic Cassis adzes from the site, found with pottery in the upper layers $(30-35 \mathrm{~cm})$ and certainly younger than 3500 years on typological grounds, yet with a direct C14 date on the shell of 10,621-10,246 years ago (OZD773). A third Hippopus specimen from 145-150 cm (Fig. 9.4(a)) actually gave a younger date than the c. 12,000 years expected, of only 7176-6771 years (OZD774), confirming that it had probably been cached in a hole. This one was quite possibly made of fresh shell.

What can we conclude from these dates? That for the Hippopus specimen of c. 7000 BP seems a reasonable estimate for its manufacture, given that the Golo Tridacna and Hippopus adzes predated the appearance of pottery in the site and lay a little below the oldest animal bones, which also apparently commenced deposition 
around 7000 years ago (see Chapter 10). These Tridacna and Hippopus shell adzes, therefore, are certainly not Neolithic - they document indigenous late Palaeolithic enterprise and no doubt ocean crossing if we are to explain the Gebe and Admiralty parallels. None of the Admiralty specimens have been directly dated, but, as stated above, the excavators (Frederickson et al. 1993) obtained terminal Pleistocene to middle Holocene dates from the sediments in which they were found, suggesting an actual age during the Holocene for the adzes themselves. However, whatever the precise date for these shell adzes, which may always be uncertain owing to the problems with direct dating of shell, it is interesting that absolutely no other crafted (as opposed to simply flaked) shell artefacts occurred in the Northern Moluccan pre-Neolithic—no beads, no bracelets, no fish-hooks.

\section{Glass beads from Uattamdi 1}

The Uattamdi 1 Neolithic shell beads are discussed by Katherine Szabó in Chapter 9, but examination of Table 5.1 will indicate that 118 glass beads of the Early Metal Phase were also recovered from the Uattamdi excavations, concentrated in Layer B with the burial jar sherds. A few had also worked their way downwards through the stratigraphy into the upper part of Layer C, with its Neolithic pottery. The shell beads, on the contrary, were found mainly in Layers C and D, with only three in Layer B. The Uattamdi glass beads were not analysed chemically and have now been returned to Indonesia, but in the interests of future comparative research I have located a series of $35 \mathrm{~mm}$ colour print photos of the Uattamdi shell, stone, and glass beads taken during the 1990s, and scanned and inserted them into Figure 8.8. Not all the glass beads found in Uattamdi 1 are shown, but the photograph shows all the bead types that were present. All of glass were monochrome Indo-Pacific beads in the terminology of Peter Francis $(1990,2002)$.

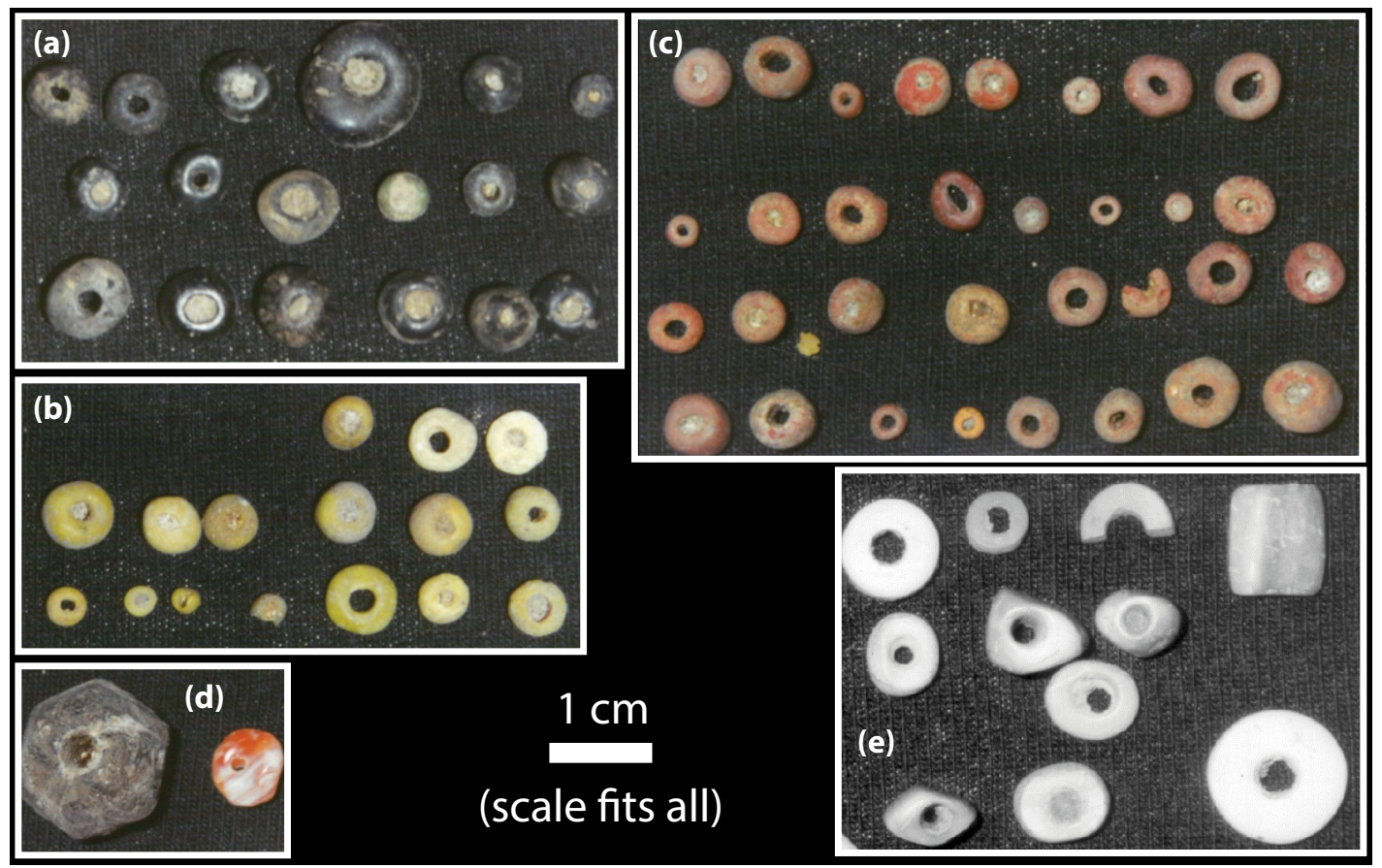

Figure 8.8 Monochrome glass beads (a-c), two stone beads (d), and shell beads (e) from Uattamdi 1. These are scanned archival photos.

Source: Peter Bellwood. 
This text is taken from The Spice Islands in Prehistory: Archaeology in the Northern Moluccas, Indonesia, edited by Peter Bellwood, published 2019 by ANU Press, The Australian National University, Canberra, Australia. 